\section{Praktische Metallographie Practical Metallography}

\begin{abstract}
Gründer/Founders
Günter Petzow

Gerhard Reinacher $†$

Charlotte Wachau +

\section{Herausgeber/Editor}

Prof. Dr. G. Petzow

Max-Planck-Institut für

Metallforschung

Heisenbergstraße 5,

D-70569 Stuttgart

\section{Schriftleitung/}

Editor in charge

Prof. Dr. H. E. Exner

Technische Hochschule

Darmstadt, FB 21:

Materialwissenschaften,

Petersenstraße 30,

D-64287 Darmstadt
\end{abstract}

\section{Redaktionssekretariat/} Secretary

Karin Exner

Auf der Marienhöhe 5,

D-64297 Darmstadt,

Telefon 06151/537165

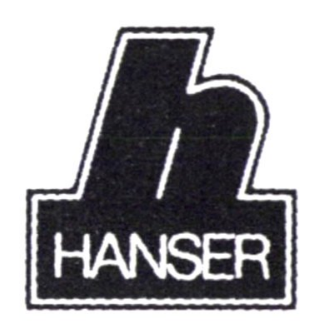

Carl Hanser Verlag, München

\title{
Inhalt/Contents
}

M. Kallfass, G. Hörz, Metallkundliche Untersuchungen an Schmuck- und Zeremónialgegenständen aus dem Fürstengrab von Sipán/Peru

Teil 1: Einleitung, Probenpräparation und Untersuchungsmethoden - Studien an Gegenständen aus Kupfer (Sargverschlußbänder, Trennstäbe eines Perlenkragens)

Metallographic Investigations of Ornamental and Ceremonial Objects from the Royal Tomb of Sipán/Peru

Part 1: Introduction, Sample Preparation and Methods of Investigation - Studies on Copper Objects (Coffin Straps, Spacer Bars of a Beaded Pectoral)

Mitteilungen/Information 649

Tagungskalender/Meeting Diary 650

Impressum 652

Jahresindex/Annual Index .653

\section{Wissenschaftlicher Beirat/Editorial Board}

Dr. Chris Bagnall, Concurrent Technologies Corp., 1450 Scalp Av., Johnstown, PA 15904, USA . Prof. Dr. H.-E. Bühler, Didier-Werke AG, Lessingstraße 16-18, D-65189 Wiesbaden · Dr. J. L. Chermant, LERMAT, I.S.M.R.A.-Université, F-14032 Caen Cedex · Volkmar Dietl, Lette-Verein, Viktoria-Luise-Platz 6, D-10777 Berlin . Dr. G. Elssner, Max-Planck-Institut für Metallforschung, Seestraße 92, D-70174 Stuttgart · R. J. Gray, 137 Orchard Lane, Oak Ridge, Tenn. 37830, USA . Prof. Dr. E. Hornbogen, Ruhr-Universität Bochum, Universitätsstr. 150, D-44780 Bochum · Prof. Dr. H. P. Hougardy, Max-Planck-Institut für Eisenforschung GmbH, Max-Planck-Straße 1, D-40237 Düsseldorf · Prof. Dr. F. Jeglitsch, Montanuniversität, A-8700 Leoben · Dr. W.-U. Kopp, Struers GmbH, Albert-Einstein-Straße 5, D-40699 Erkrath . Prof. Dr. G. Ondracek, Institut für Gesteinshüttenkunde, RWTH, Mauerstraße 5, D-52064 Aachen · Prof. Dr. M. PohI, Ruhr-Universität Bochum, Universitätsstr. 150, D-44780 Bochum - Prof. B. Ralph, Brunel University, Uxbridge, Middlesex UB8 3PH, UK . Dr. P. Wellner, Wirtz Buehler GmbH, In der Steele 2, D-40599 Düsseldorf 


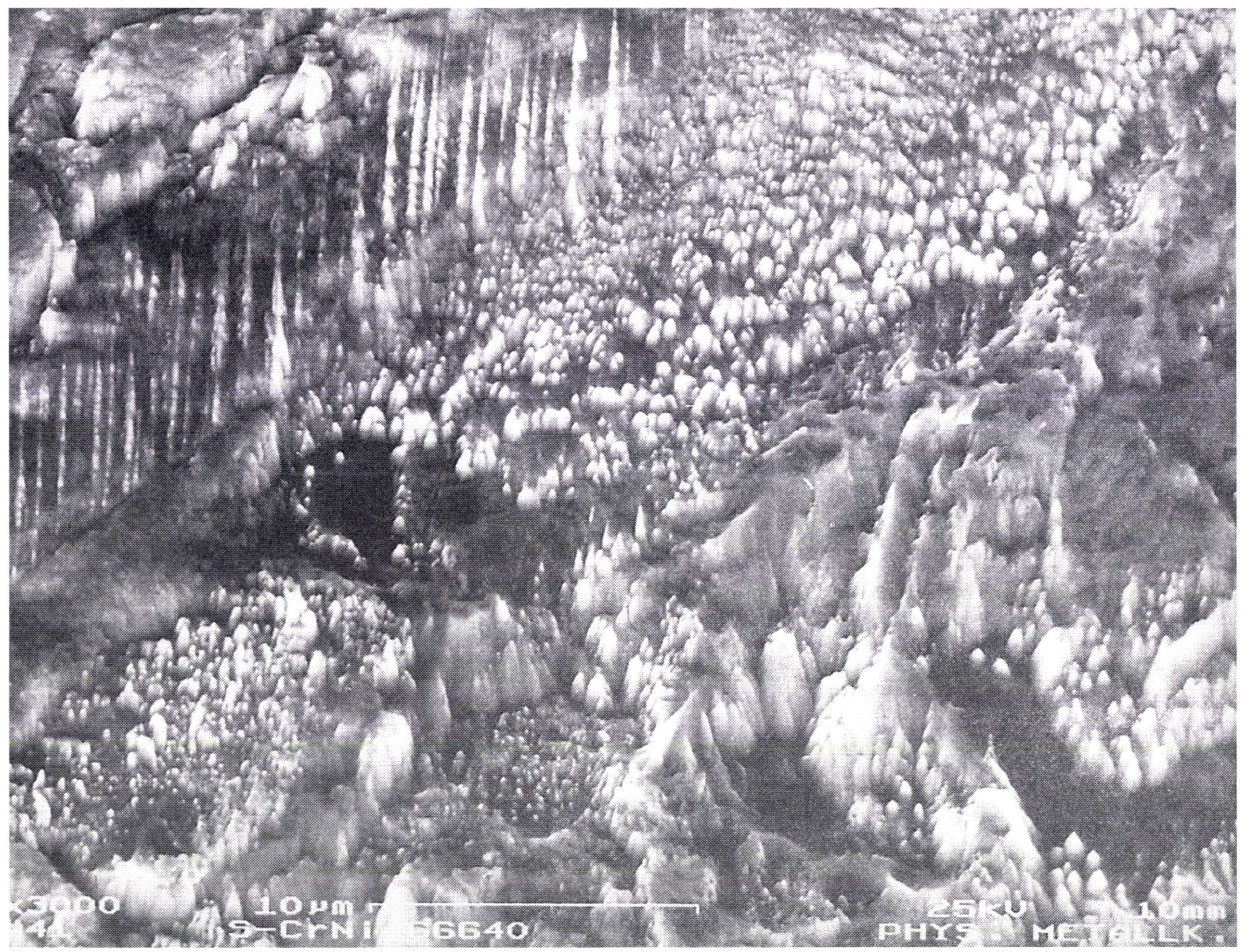

Durch lonenätzung hervorgerufene Artefakte in der Wärmeeinflußzone einer Schweißverbindung Artifacts formed during ion etching in the heat affected zone of a welded joint

(Aufnahme/micrograph: Isolde Gräf, Technische Hochschule Darmstadt, FB Materialwissenschaft, FG Physikalische Metallkunde, Darmstadt)

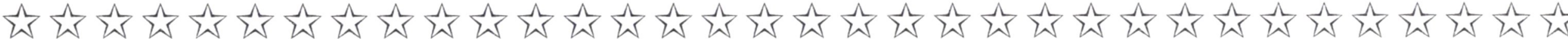

光

Unseren Lesern, Autoren und Freunden wünschen wir ein frohes Weihnachtsfest und ein glückliches und erfolgreiches neues Jahr. Herausgeber, Schriftleitung und Verlag

The best for a merry Christmas and a happy and successful New Year to our readers, authors and friends. Editor, editorial board, and publisher

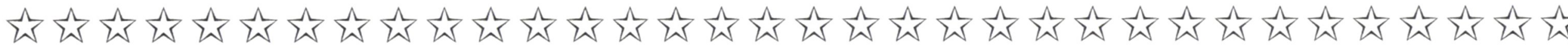




\title{
Metallkundliche Untersuchungen an Schmuck- und Zeremonial- gegenständen aus dem Fürstengrab von Sipán/Peru
}

\author{
Teil 1: Einleitung, Probenpräparation und Untersuchungs- \\ methoden - Studien an Gegenständen aus Kupfer (Sargver- \\ schlußbänder, Trennstäbe eines Perlenkragens)
}

\section{Metallographic Investigations of Ornamental and Ceremonial Objects from the Royal Tomb of Sipán/Peru}

\section{Part 1: Introduction, Sample Preparation and Methods of Investigation - Studies on Copper Objects (Coffin Straps, Spacer Bars of a Beaded Pectoral)}

\begin{abstract}
Monika Kallfass, Gerhard Hörz
(Max-Planck-Institut für Metallforschung, Institut für Werkstoffwissenschaft, Stuttgart)
\end{abstract}

\section{Einleitung}

In der vorliegenden und in weiteren Mitteilungen [1] wird über die Ergebnisse metallkundlicher Untersuchungen an Fundstücken aus dem Fürstengrab von Sipán/Peru (Moche-Kultur) berichtet. Die an unserem Institut durchgeführten umfangreichen Arbeiten erfolgten auf Anregung und in Zusammenarbeit mit dem Römisch-Germanischen Zentralmuseum in Mainz, das mit der Konservierung und Restauration eines großen Teils der Grabbeigaben betraut worden war. Ausgangspunkt unseres Interesses waren die für das Südamerika der präkolumbianischen Zeit charakteristischen Besonderheiten bei der Herstellung von Gegenständen aus Kupfer sowie KupferSilber-, Kupfer-Gold- und Kupfer-Gold-Silber-Legierungen durch abwechselndes Hämmern und Glühen (Blechtechnik) und durch Oberflächenvergoldung oder -versilberung. Diese Techniken wurden insbesondere von $H$. Lechtman in den letzten Jahren eingehend beschrieben und diskutiert [27]. Die in großer Zahl und Vielfalt aus dem Fürstengrab von Sipán geborgenen überaus wertvollen Gegenstände eröffneten nun die einmalige Gelegenheit, durch die Untersuchung ausgewählter Proben zur weiteren Aufklärung der Fragen der chemischen Zusammensetzung und der Herstellung von metallischen Schmuck- und Zeremonialgegenständen in der Moche-Zeit beizutragen.
Introduction

In this, and a number of future articles [1], the results of metallurgical investigations carried out on artifacts found in the Royal Tomb of Sipán/Peru (Moche culture) will be reported. The extensive work, carried out at our institute, was a result of collaboration between ourselves and the "Römisch-Germanischen Zentralmuseum" in Mainz, which was entrusted with the conservation and restoration of a large part of the finds recovered during the excavation. Starting point of our interest were in particular special techniques used by the pre-Columbians to manufacture objects from copper, copper-silver-, copper-gold- and copper-gold-silver-alloys by hammering and annealing (sheet technology) and by surface gilding or silvering. These methods have been reported and discussed in recent years, especially by $H$. Lechtman [2-7]. The numerous, multifarious and exceedingly valuable artifacts recovered from the Royal Tomb of Sipán offered a unique opportunity, by investigating certain chosen specimens, to clarify unanswered questions regarding the chemical composition and methods of manufacture of metallic ornamental and ceremonial objects from the Moche period. 